\title{
A strange type of addiction
}

David L. Hull

The Selfish Gene, new edition. By Richard Dawkins. Oxford University Press: 1989.

Pp. 352. Hbk £17.50, \$22.95; pbk £5.95.

The Selfish Gene appeared in 1976. Dawkins wrote the book to educate general readers about biological evolution, to prod experts out of their slumbers over the issue of individual selection and to catch the imagination of students. He succeeded on all counts. For this second edition, he has not engaged in rewriting on a large scale. Instead he has added two chapters at the end and interspersed his text with footnotes in which he acknowledges errors, expands on certain points and replies to his critics. The result is a more moderate and conciliatory book than the original. Dawkins has caught our attention. Now he can afford to present his views in more measured terms.

One of the issues that has fascinated Dawkins is exactly how nice we can be given the constraints placed on us by biological evolution, in particular the 'selfishness' of genes. He is not impressed by objections that genes can no more be selfish or unselfish than atoms can be jealous. Scientists have always borrowed words from ordinary language and transformed them into technical scientific terms. If Newton could use the Latin equivalent to 'force' to characterize mass, and quantum physicists can talk about a subatomic particle having 'charm', then biologists are justified in turning 'selfishness' into a technical term as well. Unfortunately, some choices can lead to misunderstandings - the selfishness of genes in the technical sense has consequences for the selfishness of organisms in a more ordinary sense, and the two are easily confused.

Dawkins is swayed more by objections that turn on the social implications of his way of expressing himself. He began working on 'The Selfish Gene in 1972 when power-cuts resulting from industrial strife forced him to interrupt his laboratory research. At the time the behaviour of the working classes in Britain seemed to offer increasingly good examples of selfish short-sightedness. But times have changed: "Now that Britain has a government of the new right, which has elevated meanness and selfishness to the status of ideology, my words seem to have acquired a kind of nastiness by association that I regret" (p. 268 ). He also regrets his overly cynical and selfish view of life expressed in his chapter on the battle of the sexes, but at the time he felt the need to counteract the Pollyannaish view then prevalent of the relation between the sexes.

In the original book, Dawkins acknowledged that a "human society based simply on the gene's law of universal ruthless selfishness would be a very nasty society in which to live". In part he intended to warn us that if we want, as he does, to "build a society in which individuals cooperate generously and unselfishly towards a common good, you can expect little help from biological nature" (p. 3). Our only hope for a better society is to understand our biological make-up and to counteract it. As surprising as it might sound coming

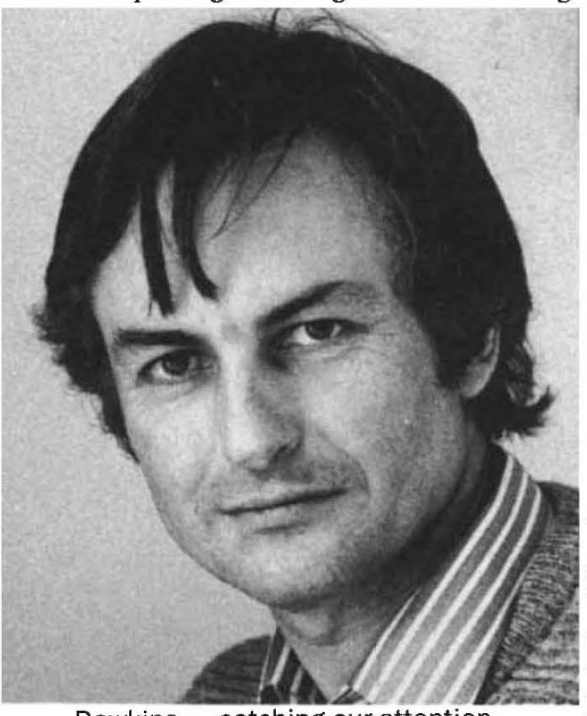

Dawkins - catching our attention.

from someone who has so strongly emphasized the role of genes in biological evolution, Dawkins nevertheless insists that "Darwinism is too big a theory to be confined to the narrow context of the gene" (p. 191). Genes function as the replicators in biological evolution while memes serve this same function in cultural evolution.

Early darwinians such as Huxley presented their contemporaries with the choice of either darwinism or miracles. Dawkins seems to be presented with a comparable dilemma - either genetic determinism or free will. He insists that he was not and never has been a genetic determinist. Genes exert the same sort of statistical influence on behaviour as on other phenotypic traits. Genes are necessary. They are never sufficient. The influence of genes can be "modified, overridden or reversed by other influences" (p. 331). These other influences are to be found in our environment, especially in our society. "We, that is our brains, are separate and independent enough from our genes to rebel against them" (p. 332). The crucial issue is our power to influence which memes come to reside in our brains. Memetic determinism is no less deterministic than genetic determinism. We can rebel against our genes, but can we rebel against our memes? Science is one way. If science is anything, it is a method that can force us to change even our most cherished memes.

The two additional chapters added by Dawkins are entitled "Nice Guys Finish First" and "The Long Reach of the Gene". The first corrects and expands upon his earlier discussion of evolutionarily stable strategies. If one looks at simple versions of such game - theoretical problems as the Prisoners' Dilemma, it is difficult to see how cooperative behaviour can become prevalent. Nice guys cannot win. But in real life organisms play repeated (or iterated) games. Behaviour that has a low payoff if each game is made up of new players can become prevalent if successive games are played with the same contestants. In iterated games it turns out that the nastier strategies rarely prevail - and selection is inherently an iterated game. Thus, Dawkins concludes that "even with selfish genes at the helm, nice guys can finish first" (p. 223). But notice that genes are still at the helm.

The other new chapter is not concerned with who is nasty and who is nice but with the basic structure of selection processes themselves. For all the modifications that Dawkins has introduced into his theory, he still argues for the primacy of genes, but he now sees more clearly in what ways they are more primary than organisms. In selection processes entities must replicate themselves. They must interact causally with their environments in such a way that replication is differential. Differential replication in the absence of such environmental interaction is drift, not selection. Dawkins terms the entities that perform the first function "replicators". According to him, genes are the sole replicators in biological evolution. Replicators can interact directly with their environments or produce more inclusive entities (vehicles) that perform this function for them.

One of the reasons why Dawkins wrote The Selfish Gene was to combat the alacrity with which so many ethologists explained certain behaviours in terms of group selection. "We can now see that the organism and the group of organisms are true rivals for the vehicle role in the story, but neither of them is even a candidate for the replicator role" (p. 254). Organisms and even certain sorts of colonies can function in selection processes - as vehicles, not replicators. Dawkins is a genic replicationist, not a genic selectionist.

The part of the second edition that I found most valuable is Dawkins's reworking of the foundations of our understanding of the evolutionary process. All that is necessary for selection to occur is that genes have phenotypic effects. But, in point of fact, genes are organized into genomes, they gang up in cells, cells gang up into multicellular organisms and some organisms gang up in colonies. If discrete, 


\section{Selected titles from Kluwer}

\section{Alternative Life-History Styles of Animals}

\author{
edited by Michael N. Bruton \\ PERSPECTIVES IN VERTEBRATE SCIENCE 6
}

Fresh and sometimes controversial insights are provided on the consequences of bifurcation for epigenesis and evolution, and a suggestion is made that new paradigms are emerging which emphasize the harmonious self-organization of natural systems (cells, organisms, communities and ecosystems).

1989, 624 pp.

ISBN 90-6193-662-4

Hardbound Dfl. $400.00 /$ \& $129.00 /$ US $\$ 215.00$

\section{Inland Waters of Southern Africa: An Ecological Perspective}

by B. R. Allanson, R. C. Hart,

J. H. O'Keeffe and R. D. Robarts

MONOGRAPHIAE BIOLOGICAE 64

The book commences with a scene-setting review (in four chapters) of the relevant aspects of the sub-continent, followed by a discussion of the river and its catchment, floodplains and wetlands, and of natural and man-made lakes. The various data are drawn together in the last section, which is devoted to a synthesis and the implications of the findings. Extensive references and index complete the work

1989, 464 pp. ISBN 0-7923-0266-4 Hardbound Dfl. $300.00 / £ 100.00 /$ US $\$ 159.00$

\section{Acid Waters in Wales}

by R. W. Edwards, A. S. Gee and

\section{J. H. Stoner}

MONOGRAPHIAE BIOLOGICAE 66

The book deals with: Evidence for Acidification (Paleo-ecological and contemporary); Causes of Acidification; Effects of Acidification (on ecology, fisheries and water-supply); Catchment studies (including hydrochemical and biological modelling) and Potential Solutions. Chapters on Ecotoxicological Studies and the Chemistry of Aluminium are included.

1990 ISBN 0-7923-0493-4 Hardbound price to be announced

\section{Evolution of Laurussia}

A Study in Late Palaeozoic Plate Tectonics

\section{by Peter $\mathbf{A}$. Ziegler}

This volume provides earth scientists with an overview of the late Palaeozoic evolution of North America, Europe, the Arctic and North Africa in a plate tectonic framework.

1990, 100 pp. ISBN 0-7923-0428-4 Hardbound Dfl. 145.00/£49.00/US $\$ 69.00$

\section{KLUWER ACADEMIC PUBLISHERS \\ P.O. Box 322, 3300 AH Dordrecht, \\ The Netherlands \\ P.O. Box 358, Accord Station, Hingham, \\ MA 02018-0358, U.S.A}

Reader Service No.26 individually purposeful vehicles are not necessary for selection, why are there so many of them? And why do multicellular organisms adopt a 'bottlenecked' life cycle?

The crucial distinction for Dawkins is not between sexual and asexual reproduction, but between those organisms that periodically go through cellular bottlenecks and those that do not. In the second case, no difference exists between growth and reproduction. Mutated cells find themselves clumped with distantly related cells that retain the original genetic makeup. But organisms that go through singlecelled bottlenecks can go back to the drawing board. Instead of attempting to reorganize an entire organism, all that has to be modified is a single genome. Sequestering certain cells into germ lines facilitates the evolution of complex organisms. This mode of organization seems so advantageous, one wonders why it is not universal. Clonal organisms must be doing something right because they are still with us.

Although Dawkins grants that bare genes are invisible to natural selection, he argues that natural selection acts on genes through differences in their phenotypic effects, and these effects need not stop at the boundaries of our bodies. They extend to all the effects that a gene has on the world, including responses in the behaviour of other organisms. Thus, both Dawkins's book and the responses to it count as part of his extended phenotype. In one place, he describes an adult dunnock feeding a cuckoo chick that it has been tricked into adopting. The dunnock is so much smaller than the cuckoo chick that it must perch on the back of this monstrous foster-child to feed it. Dawkins remarks that German ornithologists refer to such foster-parents as 'addicts' and their cuckoo nestlings as their 'vice'. As I read this description, I pictured him perched atop his theory attempting to feed its gaping mouth. Scientists give every appearance of being addicts, and science is their vice. That is one reason why progress in science is so rapid. I for one have benefited a great deal from Dawkins's addiction.

David L. Hull is in the Department of Philosophy, Northwestern University, Evanston, IIlinois 60208, USA.

Some of the attractions and pitfalls of this emerging discipline are amply illustrated by the two books under review. Asimov's is the easier to read, because he writes short, discursive essays, mostly of around 200 words, for most of the discoveries or inventions covered. There is something for every year since 1793 and for most years from about 1600 . It all becomes rather formulaic: 1902 and 1970 were good years, with eleven entries each, whereas 1958 and 1928 were rather ordinary, with only five. Fleming's discovery of penicillin gets about as much space as Marguerite Perey's discovery of francium, Diderot's Encyclopédie about as much as the fifth satellite of Jupiter (Amalthea).

Asimov ends with the greenhouse effect, 4,001,988 years after his first entry, on bipedality, thereby giving a symmetry to the volume - if the first process had not occurred, neither would the last. In between there is much to admire but also everything to take on trust. As befits the author of 425 other books, Asimov has eschewed preface, acknowledgements, references or bibliography. The only personal touch is a dedication.

Hellemans and Bunch (both of whom are science editors) don't tell us where they got their information from either, although in the preface they acknowledge help and provide the useful information that they "have relied upon the consensus of many historians of science whose works we consulted to help locate the events as closely as possible". They record about 10,000 separate items, ranging from a birth or a death to a publication, experiment or invention. Throughout, a 'general' 